\title{
Invasive Insects (Adventive Pest Insects) in Florida ${ }^{1}$
}

J. H. Frank and M. C. Thomas ${ }^{2}$

\section{What is an Invasive Insect?}

The term 'invasive species' is defined as 'non-native species which threaten ecosystems, habitats, or species' by the European Environment Agency (2004). It is widely used by the news media and it has become a bureaucratese expression. This is the definition we accept here, except that for several reasons we prefer the word adventive (meaning they arrived) to non-native. So, 'invasive insects' in Florida are by definition a subset (those that are pests) of the species that have arrived from abroad (adventive species $=$ non-native species $=$ nonindigenous species). We need to know which insect species are adventive and, of those, which are pests.

\section{How to Know That a Species is Adventive}

In Florida, 500 years ago, nobody identified and made lists of insect species present. So there is a lot of detective work, and many guesses by insect taxonomists, in knowing which ones were present then (are native), and which arrived since then (are adventive). Recent arrivals are a lesser problem because we now have lists. There still are problems because the lists are incomplete. The lists do not include some of the more obscure native species, which still are unrecorded; they do not include some of the adventive species that have not yet been detected and/or identified; and they do not specify the origin (native or adventive) of many species.

\section{How to Recognize a Pest}

A value judgment must be made: among all adventive species in a defined area (Florida, for example), which ones are pests? We can classify the more prominent examples, but cannot easily decide whether the vast bulk of them are 'invasive' (= pests) or not, for lack of evidence. To classify them all into pests and non-pests we must draw a line somewhere in a continuum ranging from important pests through those that are uncommon and feed on nothing of consequence to humans, to those that are beneficial.

Florida has at least 12,500 insect species. They all eat something. Whether humans call them pests depends partly on their abundance, partly on whether humans value or denigrate what these insects eat, and partly upon extraneous concepts. There is no rule about what people call a pest. After all, by Federal law, any insect that eats plants is a 'plant pest' although some insects that eat plants are caterpillars

1. This document is ENY-827, one of a series of the Entomology \& Nematology Department, Florida Cooperative Extension Service, Institute of Food and Agricultural Sciences, University of Florida. Published: May 2004. For more publications related to horticulture/agriculture, please visit the EDIS Website at http://edis.ifas.ufl.edu/.

2. J. H. Frank, professor, Entomology and Nematology Department, Institute of Food and Agricultural Sciences, University of Florida, Gainesville, FL and M. C. Thomas, Florida State Collection of Arthropods, Division of Plant Industry, Gainesville, FL.

The Institute of Food and Agricultural Sciences is an equal opportunity/affirmative action employer authorized to provide research, educational information and other services only to individuals and institutions that function without regard to race, color, sex, age, handicap, or national origin. For information on obtaining other extension publications, contact your county Cooperative Extension Service office. Florida Cooperative Extension Service/Institute of Food and Agricultural Sciences/University of Florida/Christine Taylor Waddill, Dean. 
of 'endangered species' of butterflies under Federal law. Even Federal laws are inconsistent.

Because we had no easy means of deciding all that are pests, we avoided the issue by selecting 100 important adventive pest insects ('invasive insects'). We list them (Table 1) by order, and then by family, genus and species, all alphabetical.

For each species, we give the date of detection in Florida, accurately for fairly recent arrivals, or approximately for older arrivals if we found any information, but for a few of them we found no information and simply leave the year of arrival with a question mark. We do not really know whether they are the 100 worst, but we guess they may be, or many of them potentially were at the time of their arrival, although accurate economic data are not available. We give the common name if there is one.

\section{Conclusion}

Insects have been arriving in Florida for thousands of years, in fact ever since the peninsula was last exposed by dropping sea levels. But it has only been in the last 30 years or so that the rate of insect immigration into Florida has been documented (Frank and McCoy 1992; Thomas 2004). During the decades since 1971 exotic insects have been arriving and becoming established on Florida's shores at a rate of about 10 species per year. In other words, Florida's insect fauna increases by one species every five weeks. This is counting only those species for which there is evidence that the species are breeding in Florida; it does not count port interceptions; it does not count the few insects introduced/established for biocontrol of pests.

Table 1. A hundred important invasive insects in Florida.

\begin{tabular}{|c|}
\hline BLATTARIA: BLATTELLIDAE \\
\hline Blattella asahinai Mizukubo, Asian cockroach, from Asia, a pest of ornamental plants and crops. 1986. \\
\hline Blattella germanica (L.), German cockroach, from Europe, a household pest. $19^{\text {th }}$ century. \\
\hline BLATTARIA: PERIPLANETIDAE \\
\hline Periplaneta americana (L.), American cockroach, from Africa, a household pest. $17^{\text {th }}$ century. \\
\hline Periplaneta australiae (F), Australian cockroach, from Africa, a household pest. 1877. \\
\hline COLEOPTERA: CHRYSOMELIDAE \\
\hline Chelymorpha cribraria (F.), no common name, from the American tropics, a pest of native Ipomoea plants. 1993. \\
\hline $\begin{array}{l}\text { Diabrotica balteata LeConte, banded cucumber beetle, from the southwestern USA, Mexico, and Central America, a } \\
\text { pest of cucurbits and some other vegetables. Early } 20^{\text {th }} \text { century. }\end{array}$ \\
\hline Leptinotarsa decemlineata (Say), Colorado potato beetle, from the western USA, a pest of potato. 1920. \\
\hline COLEOPTERA: COCCINELLIDAE \\
\hline Epilachna varivestis Mulsant, Mexican bean beetle, from Central America, a pest of beans. 1920. \\
\hline COLEOPTERA: CURCULIONIDAE \\
\hline Anthonomus grandis Boheman, boll weevil, from southern Mexico, a pest of cotton. 1920. \\
\hline Anthonomus eugenii Cano, pepper weevil, from Mexico, a pest of sweet pepper. 1935. \\
\hline Asynonychus godmanni Crotch, Fuller rose weevil, from South America, a pest of citrus and ornamental plants. 1870. \\
\hline Cylas formicarius (F.), sweetpotato weevil, from Asia, a pest of sweet potatoes. 1878 \\
\hline $\begin{array}{l}\text { Diaprepes abbreviatus (L.), sugarcane rootstock weevil borer, or Apopka weevil, from the West Indies, a pest of citrus, } \\
\text { sugarcane, and many other plants. } 1960 \text {. }\end{array}$ \\
\hline Hypera postica (Gyllenhal), alfalfa weevil, from Europe, a pest of alfalfa. 1970. \\
\hline $\begin{array}{l}\text { Metamasius callizona (Chevrolat), Mexican bromeliad weevil, from Mexico, a pest of native and cultivated bromeliads. } \\
1989 .\end{array}$ \\
\hline $\begin{array}{l}\text { Metamasius hemipterus (L.), silky sugarcane weevil, from the Neotropics, a pest of sugarcane, ornamental palms, and } \\
\text { rarely of pineapple fruits. } 1984 \text {. }\end{array}$ \\
\hline COLEOPTERA: NITIDULIDAE \\
\hline Aethina tumida Murray, small hive beetle, from Africa, a pest of honey bees. 1998. \\
\hline
\end{tabular}


Table 1. A hundred important invasive insects in Florida.

\begin{tabular}{|c|}
\hline DIPTERA: BIBIONIDAE \\
\hline Plecia nearctica Hardy, lovebug, from Central America, damages radiators and paint of cars. 1949. \\
\hline DIPTERA: BRAULIDAE \\
\hline Braula coeca Nitzsch, beelouse, from Europe, a pest of honey bee. 1983. \\
\hline DIPTERA: CALLIPHORIDAE \\
\hline $\begin{array}{l}\text { Cochliomyia hominivorax (Coquerel), New World screwworm, from the Neotropics, a pest of cattle and other } \\
\text { vertebrates including humans. 1933. Eradicated by use of the sterile-male technique. }\end{array}$ \\
\hline DIPTERA: CULICIDAE \\
\hline Aedes aegypti (L.), yellow fever mosquito, from Africa, a vector of yellow fever and dengue. Before 1850. \\
\hline Aedes albopictus (Skuse), Asian tiger mosquito, from eastern Asia, a vector of dengue. 1986. \\
\hline DIPTERA: MUSCIDAE \\
\hline Haematobia irritans (L.), horn fly, from Africa, a pest of cattle. 1890. \\
\hline Musca domestica L., house fly, from Africa, a pest of humans and livestock. Before 1850. \\
\hline Stomoxys calcitrans (L.), stable fly, from Africa, a pest of livestock and humans. 1900. \\
\hline DIPTERA: OESTRIDAE \\
\hline Gasterophilus haemorrhoidalis L.), nose botfly, from Europe, a pest of horses. Before $19^{\text {th }}$ century. \\
\hline Gasterophilus intestinalis (DeGeer), horse botfly, from Europe, a pest of horses. Before $19^{\text {th }}$ century. \\
\hline Gasterophilus nasalis (I.), throat botfly, from Europe, a pest of horses. Before $19^{\text {th }}$ century. \\
\hline Hypoderma bovis (L.), northern cattle grub, from Europe, a pest of cattle. Before $19^{\text {th }}$ century. \\
\hline Hypoderma lineatum (Villers), common cattle grub, from Europe, a pest of cattle. Before $19^{\text {th }}$ century. \\
\hline Oestrus ovis (L.), sheep botfly, from Europe, a pest of sheep. Before $19^{\text {th }}$ century. \\
\hline DIPTERA: TEPHRITIDAE \\
\hline Anastrepha suspensa (Loew), Caribbean fruit fly, from the West Indies, a pest of cultivated fruits. 1931. \\
\hline $\begin{array}{l}\text { Ceratitis capitata (Wiedemann), Mediterranean fruit fly, from subsaharan Africa, a pest of fruits. Detected several times, } \\
\text { beginning in } 1929 \text {, and eradicated at great expense each time. }\end{array}$ \\
\hline Toxotrypana curvicauda Gerstaecker, papaya fruit fly, from the Neotropical region, a pest of papaya. 1905. \\
\hline HEMIPTERA: PENTATOMIDAE \\
\hline $\begin{array}{l}\text { Euschistus quadrador Rolston, a brown stink bug, from Mexico, has supplanted other stink bugs in cotton, soybean, } \\
\text { citrus, and other crops. Early 1990s. }\end{array}$ \\
\hline Nezara viridula (L.), southern green stinkbug, from Africa, a pest of vegetables. Before 1850. \\
\hline HEMIPTERA: TINGIDAE \\
\hline Leptodictya tabida (Herrich-Schaeffer), sugarcane lace bug, from the Neotropics, a pest of sugarcane. 1990. \\
\hline HOMOPTERA: ALEYRODIDAE \\
\hline Aleurocanthus woglumi Ashby, citrus blackfly, from Asia, a pest of citrus. 1930 (eradicated) and 1976. \\
\hline Aleurodicus dispersus Russell, spiralling whitefly, from the Neotropics, a pest of citrus and coconut. 1950. \\
\hline Aleurodicus dugesii Cockerell, giant whitefly, from Mexico, a pest of numerous ornamental plants. 1996. \\
\hline $\begin{array}{l}\text { Bemisia argentifolii Bellows \& Perring, silverleaf whitefly, perhaps from the Middle East, a pest of ornamental plants, } \\
\text { tomatoes, and cucurbits. } 1986 \text {. }\end{array}$ \\
\hline Bemisia tabaci Gennadius, sweetpotato whitefly, from Asia, a pest of field crops and ornamental plants. 1890. \\
\hline Dialeurodes citri (Ashmead), citrus whitefly, from Asia, a pest of citrus. 1870. \\
\hline Singhiella citrifolii (Morgan), cloudywinged whitefly, from Asia, a pest of citrus and some ornamental plants. 1900. \\
\hline HOMOPTERA: APHIDIDAE \\
\hline $\begin{array}{l}\text { Aphis gossypii Glover, melon or cotton aphid, from Eurasia, a pest of cucurbits, cotton, and many other plants, and a } \\
\text { vector of virus. Year? }\end{array}$ \\
\hline $\begin{array}{l}\text { Aphis spiraecola Patch, spirea (or spiraea) aphid, from Asia, a pest of citrus, other fruit and ornamental trees, and many } \\
\text { other plants. } 1920 .\end{array}$ \\
\hline
\end{tabular}


Table 1. A hundred important invasive insects in Florida.

Melanaphis sacchari (Zehnter), sugarcane aphid, from Asia, a pest of sugarcane. 1977.

Myzus persicae (Sulzer), green peach aphid, from Asia, a pest of tree fruits and many other plants, and an important virus vector. Year?

Therioaphis trifolii (Monell), spotted alfalfa aphid, from Eurasia, a pest of alfalfa and clover. 1960.

Toxoptera aurantii (Fonscolombe), black citrus aphid, from Asia, a pest of citrus. 1914.

Toxoptera citricida (Kirkaldy), brown citrus aphid, from Asia, a pest of citrus. 1995.

\section{HOMOPTERA: COCCIDAE}

Ceroplastes cirripediformis Comstock, barnacle scale, from Asia, a pest of citrus and ornamental plants. 1870.

Coccus hesperidum L., brown soft scale, from Asia, a pest of citrus. 1870.

Saissetia neglecta DeLotto, Caribbean black scale, from the Caribbean, a pest of citrus.1921.

\section{HOMOPTERA: DELPHACIDAE}

Perkinsiella saccharicida Kirkaldy, sugarcane delphacid, from Australia, a pest of sugarcane. 1980.

Saccharosydne saccharivora (Westwood), West Indian sugarcane delphacid (called canefly in the English-speaking Caribbean) from the Caribbean, a pest of sugarcane. Year?

\section{HOMOPTERA: DIASPIDIDAE}

Aonidiella aurantii (Maskell), California red scale, from Asia, a pest of citrus. 1890.

Aspidiotus destructor Signoret, coconut scale, from Asia, a pest of coconut palm. 1910.

Aulacaspis yasumatsui Takagi, cycad aulacaspis scale, from Asia, a pest of cycads. 1996.

Chrysomphalus aonidum (L.), Florida red scale, from Asia, a pest of citrus. 1880.

Fiorinia theae Green, tea scale, from Asia, a pest of camellia, holly, and other ornamental plants. 1910.

Lepidosaphes beckii (Newman), purple scale, from Asia, a pest of citrus. 1900.

Pseudaulacaspis cockerelli (Cooley), false oleander scale, from Asia, a pest of oleander, magnolia, mango, dogwood, etc. 1940.

Pseudaulacaspis pentagona (Targioni-Tozzetti), white peach scale, from Asia, a pest of peach and other trees. 1880.

Unaspis citri (Comstock), citrus snow scale, from Asia, a pest of citrus. 1880.

Unaspis euonymi (Comstock), euonymus scale, from Asia, a pest of ornamental plants. 1960.

HOMOPTERA: KERRIIDAE

Paratachardina lobata (Chamberlin), lobate lac scale, from India, a pest of many trees and shrubs. 1999.

\section{HOMOPTERA: PSEUDOCOCCIDAE}

Antonina graminis Maskell, Rhodesgrass mealybug, from Asia, a pest of grasses. 1940.

Dysmicoccus boninsis (Kuwana), gray sugarcane mealybug, from Asia, a pest of sugarcane. 1960.

Dysmicoccus brevipes (Cockerell), pineapple mealybug, from the American tropics, a pest of pineapple. 1910.

Maconellicoccus hirsutus (Green), pink hibiscus mealybug, from Asia, a pest of hibiscus and many other ornamental plants. 2002.

Paracoccus marginatus Williams \& Granara de Willink, papaya mealybug, from South America, a pest of papaya. 1998.

Planococcus citri (Risso), citrus mealybug, from Asia, a pest of citrus. 1890.

Saccharicoccus sacchari (Cockerell), pink sugarcane mealybug, from Africa, a pest of sugarcane. 1940.

\section{HOMOPTERA: PSYLLIDAE}

Diaphorina citri Kuwayama, Asian citrus psyllid, from Asia, a pest of citrus. 1998.

\section{HYMENOPTERA: FORMICIDAE}

Linepithema humile (Mayr), Argentine ant, from South America, a household pest. Earliest Florida specimen 1914, but probably was present in the 1890s (Mark Deyrup pers. com.).

Monomorium pharaonis (L.), pharaoh ant, from Africa, a household pest. Earliest Florida specimen 1908, but could have arrived as early as the first European explorers (Mark Deyrup pers. com.).

Paratrechina longicornis (Latreille), crazy ant, from the Old World tropics, a household pest. First Florida record 1930, but probably was present a century before (Mark Deyrup pers. com.). 
Table 1. A hundred important invasive insects in Florida.

Solenopsis invicta Buren, red imported fire ant, from South America, a health risk to humans, pest of "wildlife" and

"farm animals" and some cultivated crops, but a useful predator of some pests. First Florida specimens 1948 (Mark Deyrup pers. com.).

Tapinoma melanocephalum (F.), ghost ant, from the Old World tropics, a household pest. First Florida specimens 1930, but probably was present long before that (Mark Deyrup pers. com.).

Technomyrmex albipes (Fr. Smith), whitefooted ant, from Asia, a household pest. 1986.

\section{ISOPTERA: KALOTERMITIDAE}

Cryptotermes brevis (Walker), West Indian powderpost drywood termite, from the West Indies (although its true area of origin may be elsewhere), a pest of structures and living trees. Before 1919.

\section{ISOPTERA: RHINOTERMITIDAE}

Coptotermes formosanus Shiraki, Formosan subterranean termite, from Asia, a pest of structures. 1980.

Coptotermes gestroi (Wasmann), Asian subterranean termite (until recently, called C. havilandi Holmgren, Haviland's subterranean termite), from southeast Asia, a pest of structures. 1996.

\section{LEPIDOPTERA: GELECHIIDAE}

Pectinophora gossypiella (Saunders), pink bollworm, from Asia, a pest of cotton. 1950.

\section{LEPIDOPTERA: GRACILLARIIDAE}

Phyllocnistis citrella Stainton, citrus leafminer, from Asia, a pest of citrus. 1993.

\section{LEPIDOPTERA: NOCTUIDAE}

Alabama argillacea (Hübner), cotton leafworm, a frequent immigrant from the south, a pest of cotton.

Anticarsia gemmatalis Hübner, velvetbean caterpillar, a frequent immigrant from the south, a pest of soybean and other lequmes. 1903.

Pseudoplusia includens (Walker), soybean looper, a frequent immigrant from the south, a pest of soybean.

\section{LEPIDOPTERA: PIERIDAE}

Pieris rapae (L.), imported cabbageworm (small white butterfly), from Eurasia, a pest of cole rops. 1886.

\section{LEPIDOPTERA: PYRALIDAE}

Cactoblastis cactorum Berg, cactus moth, from South America via the Caribbean, a pest of Opuntia cacti. 1989.

Diatraea saccharalis (F.), sugarcane borer, from the West Indies and Central and South America, a pest of sugarcane. 1860.

\section{LEPIDOPTERA: TINEIDAE}

Opagona sacchari (Bojer), banana moth, from the Old World tropics, a pest of many cultivated plants. 1963.

\section{LEPIDOPTERA: YPONOMEUTIDAE}

Plutella xylostella (L.), diamondback moth, from Europe or Africa, a pest of cole crops. 1883.

\section{ORTHOPTERA: GRYLLOTALPIDAE}

Scapteriscus abbreviatus Scudder, shortwinged mole cricket, from South America, a pest of turf. 1899.

Scapteriscus borellii Giglio-Tos, southern mole cricket, from South America, a pest of turf. 1924.

Scapteriscus vicinus Scudder, tawny mole cricket, from South America via Georgia, a pest of turf- and pasture-grasses and vegetables. 1919.

\section{THYSANOPTERA: THRIPIDAE}

Frankliniella occidentalis (Pergande), western flower thrips, from the western USA, a pest of tomato and ornamental plants. 1982.

Selenothrips rubrocinctus (Giard), redbanded thrips, from Asia or Africa, a pest of tropical/subtropical fruit and ornamental trees. Year? 
Table 1. A hundred important invasive insects in Florida.

Thrips palmi Karny, melon thrips, from Asia, a pest of greenhouse crops. 1990.

The list above includes only the species that we judge to be or have been major pests. They are only a small proportion, less than a tenth, of the insect species that arrived in Florida in the last 500 years. We do not include pre-Columbian arrivals because we interpret Federal law as indicating these are to be considered native. Amerindians are naturalized natives under Federal law, so we accord the same status to the human lice and dog fleas which probably arrived with them and have undergone far more generations here than have the Amerindians because they breed several times each year. We did not try to rank these pests in order of importance. One way of doing this would be to evaluate annual losses and costs of control caused by each in dollars. However, that would ignore pests that were historically important, but are now controlled permanently by biological control, such as the major pests of citrus. Without biological control of citrus pests, there would be no Florida citrus industry. Household pests (mainly termites and ants) are now the most costly pests, because biological control for them is difficult to develop inside dwellings, so huge sums are spent on chemical treatments giving no more than temporary control.

Although the rate of immigration seems to have held relatively steady over the past 30 years, the source of the immigrants has been changing. Earlier in that time period, the major source of immigrants was the New World tropics (the Caribbean, Central America, South America). During the 1990s, though, there was a steady increase in species from other parts of the world, especially Asia, so that now immigrant species from the Old World almost equal those from the New World. Given the relaxation of trade barriers and the increasing trade with Asia, it is a trend that promises to continue.

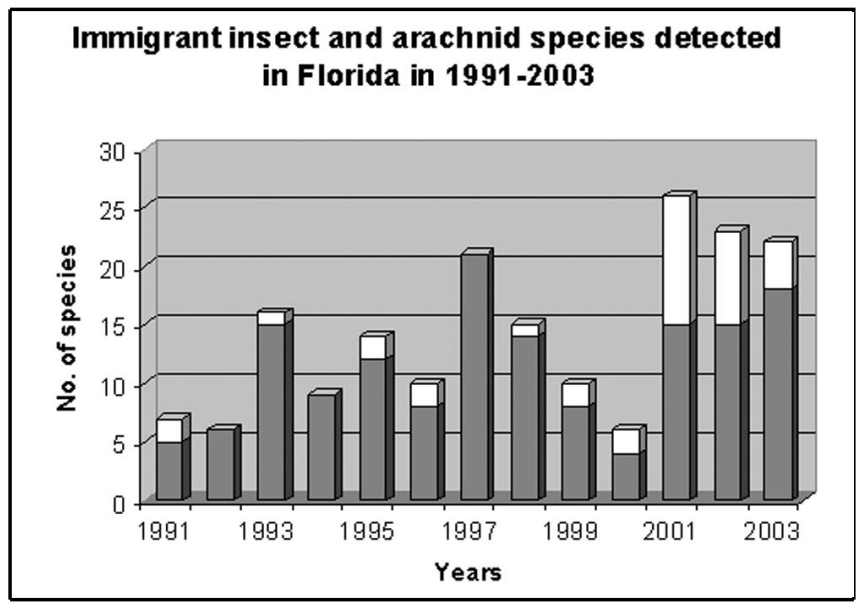

Figure 1. Immigrant insect (dark part of bar) and arachnid (white part of bar) species newly detected in Florida annually in 1991-2003. It is not yet clear how many of these species will prove to be pests ('invasive species'). The totals are 150 insects and 35 arachnids. Source: DPI records/ M.C. Thomas (2004).

\section{Explanation of Terms Used Here}

There are other definitions of 'invasive species', but the one we found in U.S. law (Executive Order
13112 of 1999) is unacceptable because it limits 'invasive species' to species that 'were introduced.' The writers of that definition paid no attention to the way that insects arrive in Florida, and so used the wrong word. That word (introduced) is as inappropriate as saying that all the people now in Florida who were not born here 'were introduced': of course they were not introduced - they were immigrants - and so were most of the insects.

This explanation has been given in the literature cited. For those who are familiar with it, there is no need to read on. For those who have never heard it before, it is presented here in the context of recent information.

\section{How Insects Arrived in Florida}

During the 1970s and 1980s, 19 insect species were introduced (deliberately) and established in Florida, all as biological control agents (Frank \& McCoy 1993). None of them is a pest (invasive species). In approximately the same years, 209 insect species of foreign origin were detected in Florida for the first time. These 209 species were not introduced (nobody introduced them deliberately), so are immigrants. All of the pest species (invasive insects) that arrived during those years are immigrant species, not introduced species. They belong to the group of 209 immigrant species, not the group of 19 introduced species. There were 228 adventive species so far as we can determine, of which $19(8.3 \%)$ were introduced and are not pests. Some people argue that insects that arrive as contaminants of cargoes should be called 'accidentally introduced' and should be included within the group of introduced insects. We 
do not agree with this concept. Of the 209 immigrant insects in the 1970s and 1980s, we have evidence (Frank and McCoy 1992) that only 8\% belong to species that were detected as contaminants of cargoes. We might stretch that $8 \%$ to $24 \%$ (Frank and McCoy 1992), but still, for most immigrant insects in Florida (at very least 76\%), there is no evidence that they arrived with human help; so they flew, or drifted on aerial or marine currents, or rafted, or walked. The maximal percent of introduced species is thus 19 (introduced species) + 50 ('accidentally introduced' species) which together amount to 69 (33\% of the adventive species). The remainder $(>66 \%)$ are immigrants, not 'introduced species' by any reasonable definition).

For those reasons, the US Federal definition of invasive species as being pest species that were 'introduced' is inappropriate for the Florida insect scenario. It may apply to plants and vertebrate animals in Florida, but it does not apply to insects. The European Environment Agency (2004) definition works for all organisms, including insects in Florida; it says that invasive species are 'non-native species which threaten ecosystems, habitats, or species', and we think that 'adventive' is better than 'non-native'.

We might add some native species - those that expanded their habitat to human dwellings and imported crops, ornamental plants, and disturbed habitats - to the list of invasive species. They, too, could be called invaders. We desist from doing so only because this would cause further confusion, in an already confused topic.

\section{Acknowledgments}

We acknowledge help from Mark Deyrup (Archbold Biological Station) for information about ants, and Susan Halbert and Greg Hodges (Florida State Collection of Arthropods) for information about aphids and coccoids respectively.

\section{References}

European Environment Agency. 2004. Glossary: invasive species. <http://glossary.eea.eu.int/ EEAGLOSSARY/> then enter invassive species and click 'Find in Glossary.'
Frank, J.H., and E.D. McCoy 1990. Endemics and epidemics of shibboleths and other things causing chaos. Florida Entomologist 73: 1-9.

Frank, J.H., and E.D. McCoy. 1992. The immigration of insects to Florida, with a tabulation of records. Florida Entomologist 75: 1-28.

Frank, J.H., and E.D. McCoy. 1993. The introduction of insects into Florida. Florida Entomologist 76: 1-53.

Frank, J.H., and E.D. McCoy.1995a. Invasive adventive insects and other organisms in Florida. Florida Entomologist 75: 1-15.

Frank, J.H., and E.D. McCoy. 1995b. Precinctive insect species in Florida. Florida Entomologist 75: 21-35.

Frank, J.H, E.D. McCoy, H.G. Hall, G.F. O'Meara, and W.R. Tschinkel WR. 1997. Immigration and introduction of insects. p. 75-99 in D. Simberloff, D.C. Schmitz and T.C. Brown. Strangers in paradise. Impact and management of nonindigenous species in Florida. Island Press; Washington, DC.

Thomas, MC. 2004. The exotic invasion of Florida. A report on arthropod immigration into the sunshine state. <http://www.doacs.state.fl.us/pi/enpp/ ento/exoticsinflorida.htm> (May 2004). 